\title{
PENGARUH PEMBERIAN EKSTRAK ETANOL BUNGA CENGKEH (Syzygiumaromaticum(L.) Merr.\& Perry) TERHADAP WAKTU TIDUR MENCIT JANTAN
}

\author{
${ }^{1}$ Poppy Dwi Citra Jaluri, ${ }^{2}$ Febri Nur Ngazizah \\ ${ }^{1}$ STIKes Borneo Cendekia Medika Pangkalan Bun \\ 1email :poppyjaluri@gmail.com ${ }^{2}$ febrinurngazizah@gmail.com
}

\begin{abstract}
ABSTRAK
Telah diteliti pengaruh pemberian ekstrak etanol bunga cengkeh (Syzygium aromaticum (L.) Merr. \& Perry) terhadap waktu tidur mencit jantan galur Swiss Webster yang diinduksi dengan fenobarbital pada dosis 100, 200 dan $400 \mathrm{mg} / \mathrm{kgbb}$. Hasil menunjukkan bahwa ekstrak etanol bunga cengkeh pada dosis 200 dan 400 $\mathrm{mg} / \mathrm{kgbb}$ dapat mempersingkat onset tidur mencit yang diinduksi dengan fenobarbital, berbeda bermakna terhadap kontrol positif $(\mathrm{p}<0,05)$. Ekstrak etanol bunga cengkeh dosis $400 \mathrm{mg} / \mathrm{kgbb}$ juga dapat memperpanjang durasi tidur pada mencit yang diinduksi dengan fenobarbital berbeda bermakna terhadap kontrol positif $(\mathrm{p}<0,05)$.
\end{abstract}

Kata kunci : bunga cengkeh, hipnotik-sedatif, fenobarbital

THE EFFECT OF GIVING ETHANOL EXTRACT OF CLOVE (Syzygiumaromaticum (L.) Merr. \& Perry) ON SLEEPING SLEEP

\begin{abstract}
The effect of ethanol extract of clove (Syzygium aromaticum (L.) Merr. \& Perry) on the sleep time of male Swiss Webster strain mice has been induced with phenobarbital at doses of 100, 200 and $400 \mathrm{mg} / \mathrm{kg}$. The results showed that clove flower ethanol extract at doses of 200 and $400 \mathrm{mg} / \mathrm{kgbb}$ can shorten the sleep onset of mice induced with phenobarbital, significantly different from positive control ( $p$ $<0.05$ ). Clove flower ethanol extract at a dose of $400 \mathrm{mg} / \mathrm{kg}$ may also extend sleep duration in mice induced with phenobarbital significantly different from positive control $(p<0.05)$.
\end{abstract}

Keywords: clove flower, hypnotic-sedative, phenobarbital

\section{Pendahuluan}

Posisi Indonesia yang terletak di daerah tropis menjadikan Indonesia sebagai salah satu kawasan dengan keragaman tumbuhan yang dapat dimanfaatkan untukpengobatan. Salah satu tumbuhan asli Indonesia yang sangat dikenal adalahcengkeh.
Cengkeh banyak manfaatnya, bukan hanya digunakan untuk bumbu masak, kandungan kimianya juga banyak dimanfaatkan dalam dunia kesehatan. Khasiat cengkeh untuk kesehatan antara lain untuk mengobati inflamasi mukosa membran mulut, 
kerongkongan, atau tenggorokan, untuk pengobatan sakit gigi (analgesik), menghambat pertumbuhan bakteri, mengobati kejang perut dan sebagai obat insomnia $(1,2)$.

Beberapa uji aktivitas cengkeh yang pernah diteliti sebelumnya adalah sebagai antibakteri, antijamur, afrodisiaka,antidepresan, efek terhadap pembelajaran dan memori pada mencit, dan efek meningkatkan kesuburan pada mencit jantan yang terpapar mangan $(3,4,5,6,7,8)$.

Semua makhluk hidup termasuk tumbuh-tumbuhan mengalami pola pergantian kegiatan antara aktif dan beristirahat. Makhluk hidup juga mengalami perubahan biokimia, fisiologi dan kebiasaan siklus tidur terjaga yang terjadi pada waktu sama setiap 24 jam (9).

Tidur didefinisikan sebagai suatu keadaan bawah sadar dimana orang tersebut dapat dibangunkan dengan pemberian rangsang sensorik atau dengan rangsang lainnya. Tidur bagi manusia merupakan hal yang sangat penting, karena tidur dapat mengendalikan irama kehidupan manusia sehari-hari. Tidur harus dibedakan dengan koma, yang merupakan keadaan bawah sadar dimana orang tersebut tidak dapat dibangunkan. Setiap manusia menghabiskan seperempat sampai sepertiga dari kehidupannya untuk tidur. Setiap orang membutuhkan tidur untuk istirahat. Namun, apabila kebutuhan itu sulit terpenuhi, dapat timbul keadaan yang dikenal dengan gangguan tidur (10).

Era globalisasi pada saat sekarang ini menuntut kita sebagai manusia bekerja keras dengan begitu waktu istirahat kita menjadi terganggu. Dengan efek itu kita bisa menjadi tidak sehat, untuk itu kita membutuhkan sesuatu agar kita bisa istirahat atau menenangkan pikiran kita yaitu salah satunya dengan tidur yang cukup. Kebutuhan akan tidur dapat dianggap sebagai suatu perlindungan diri bagi organisme untuk menghindari pengaruh yang mungkin merugikan tubuh karena kurang tidur. Tidur yang cukup, mutlak diperlukan untuk regenerasi sel-sel tubuh dan memungkinkan pelaksanaan aktivitas pada siang hari dengan baik. Dalam keadaan normal, orang dewasa menunjukan pola tidur yang teratur. Gangguan tidur yang sering terjadi adalah insomnia. Insomnia adalah ketidakmampuan untuk memulai tidur, sulit mempertahankan keadaan tidur, sulit tertidur pada malam hari atau gangguan tidur yang membuat penderita merasa belum cukup tidur pada saat terbangun $(11,12)$.

Salah satu tanaman yang diketahui berpotensi sebagai hipnotik adalah cengkeh. Tanaman cengkeh mengandung metabolit sekunder flavonoid, alkaloid, terpenoid, dan minyak atsiri yang terkenal dengan kandungan eugenolnya yang mempunyai kadar 80\%-90\%. Metabolit sekunder alkaloid dan terpenoid yang terdapat pada ekstrak etanol bunga cengkeh telah diketahui berkhasiat sebagai antidepresan dengan menekan aktivitas psikomotorik (13).

\section{METODE PENELITIAN}

Penelitian ini diawali dengan pengumpulan dan determinasi tumbuhan uji, penyiapan simplisia, dan pembuatan ekstrak serta pengujian efek. Ekstrak yang dibuat adalah ekstrak dari bunga cengkeh (Syzygium aromaticum (L.) Merr. \& Perry) kering yang dibuat dengan cara maserasi dengan menggunakan cairan penyari etanol $70 \%$. Pengujian efek terhadap waktu tidur dilakukan pada mencit 
jantan galur Swiss Webster. Tiga dosis yang digunakan yaitu $100 \mathrm{mg} / \mathrm{kgbb}$, $200 \mathrm{mg} / \mathrm{kgbb}, 400 \mathrm{mg} / \mathrm{kgbb}$. Pada penelitian ini ekstrak bunga cengkeh diberikan secara oral dan 30 menit kemudian diberi fenobarbital untuk menginduksi waktu tidur. Dosis fenobarbital yang digunakan sebagai penginduksi tidur adalah $90 \mathrm{mg} / \mathrm{kgbb}$. Kemudian diamati onset dan durasi tidur pada mencit. Data yang diperoleh dari hasil penelitian diolah secara statistik dengan metode ANOVA (Analysis of Variance) dan LSD (Least Significant difference) untuk membandingkan tiga kelompok uji. Parameter keberhasilan uji yaitu dengan mengamati kecepatan waktu tidur (onset) dan lama waktu tidur pada mencit (durasi) $(29,30)$.

\section{HASIL DAN PEMBAHASAN}

Penelitian ini meliputi pengumpulan bahan, determinasi tumbuhan uji, penapisan fitokimia simplisia dan ekstrak, karakterisasi simplisia, pembuatan sediaan ekstrak etanol bunga cengkeh, serta pengamatan efek terhadap waktu tidur mencit. Bahan penelitian yaitu berupa bunga cengkeh didapatkan dari daerah Pemangkat Kabupaten Sambas. Tumbuhan yang diteliti dideterminasi di Herbarium Bandungense Sekolah Ilmu dan Teknologi Hayati ITB dengan tujuan untuk mengidentifikasi tumbuhan yang digunakan. Hasil menunjukkan bahwa tumbuhan tersebut adalah cengkeh (Syzygium aromaticum (L.) Merr.\& Perry).

Selanjutnya bunga cengkeh diolah menjadi serbuk simplisia kering, kemudian dilakukan pembuatan ekstrak. Dari 100 gram simplisia bunga cengkeh dimaserasi dengan etanol $70 \%$ selama 3 kali 24 jam sehingga diperoleh ekstrak cair, kemudian dipekatkan dengan vakum putar dan penangas air sehingga diperoleh ekstrak kental dengan bobot tetap 17,09 gram sehingga diperoleh rendemen ekstrak sebesar $17,09 \%$.

Penapisan fitokimia dilakukan terhadap simplisia bunga cengkeh. Penapisan fitokimia simplisia dilakukan untuk mengetahui keberadaan seluruh metabolit sekunder yang terkandung di dalam bunga cengkeh. Metabolit sekunder yang teridentifikasi dalam simplisia bunga cengkeh ini adalah alkaloid, flavonoid, saponin,kuinon dan steroid/triterpenoid. Penapisan dilakukan juga terhadap ekstrak etanol bunga cengkeh untuk mengetahui keberadaan senyawa metabolit sekunder yang terambil dalam proses ekstraksi. Hasilnya menunjukkan bahwa senyawa metabolit sekunder yang terkandung dalam simplisia dan ekstrak etanol bunga cengkeh adalah sama yaitu golongan alkaloid, flavonoid, saponin, kuinon dan steroid/triterpenoid.

Dari hasil kadar air simplisia bunga cengkeh didapatkan hasil 8\%, menunjukkan bahwa kadar air sesuai dengan parameter umum simplisia yaitu kurang dari 10\%, Dari hasil Susut pengeringan simplisia bunga cengkeh didapatkan hasil 9,6\% dimana susut pengeringan adalah pengukuran sisa zat setelah pengeringan pada temperatur $105^{\circ} \mathrm{C}$ selama 30 menit atau berat konstan, yang dinyatakan sebagai nilai persen. Nilai susut pengeringan yang lebih besar dari kadar air menunjukkan adanya senyawa lain yang menguap selain air seperti minyak atsiri. Kadar abu total diperoleh sebesar 4,2\%;menunjukkan bahwa kadar abu tidak memenuhi persyaratan MMI yang seharusnya yaitu kurang dari $4 \%$, mungkin dikarenakan adanya pengotor pada saat pengeringan atau pada saat 
sortasi, dimana kadar abu total merupakan indikator sisa hasil pembakaran berupa logam dan silika serta menentukan keamanan simplisia,sedangkan kadar abu larut air yaitu 2,3\%, dimana kadar abu larut air menunjukan banyaknya jumlah logam alkali tanah yang terdapat dalam simplisia bunga cengkeh dan kadar abu tidak larut asam yaitu 0,8\%, dimana kadar abu tidak larut asam merupakan indikator banyaknya jumlah logam berat yang terdapat dalam simplisia bunga cengkeh. Kadar abu total, kadar abu tidak larut asam bunga cengkeh telah memenuhi persyaran MMI yaitu kurang dari $1 \%$. Kemudian diperoleh kadar sari larut air yaitu 23\% dan kadar sari larut etanol yaitu 28\%. Uji kadar sari dimaksudkan agar dapat memberikan gambaran awal sejumlah kandungan, khasiat dan mutu simplisia, dengan cara melarutkan simplisia tersebut dalam pelarut organik tertentu (etanol atau air). Kadar sari dibedakan atas dua jenis yaitu kadar sari larut air yaitu menggambarkan senyawa yang dapat larut dalam air (polar) dan kadar sari larut etanol yaitu menggambarkan senyawa yang dapat larut dalam pelarut organik (polar, semi polar, nonpolar) kadar sari larut air dan sari larut etanol memenuhi syarat sesuai MMI yaitu lebih dari $23 \%$ dan lebih dari $26 \%$. Karakterisasi simplisia ini bertujuan untuk standarisasi simplisia.

Ekstrak yang dibuat pada penelitian ini adalah ekstrak etanol bunga cengkeh karena etanol merupakan pelarut universal yang dapat menarik seluruh senyawa aktif yang ada di tanaman tersebut sehingga diharapkan senyawa aktif yang terdapat pada bunga cengkeh dapat terekstraksi semuanya.

Fenobarbital digunakan sebagai penginduksi tidur karena fenobarbital dapat bekerja sebagai hipnotik-sedatif dengan onset yang cepat dan durasi yang panjang serta memiliki indeks terapi besar (23).

Uji waktu tidur mencit yang diinduksi dengan fenobarbital pada penelitian ini bertujuan untuk menilai onset dan lama waktu tidur mencit setelah pemberiaan sediaan uji. Tiga dosis uji yang digunakan adalah 100, 200 dan $400 \mathrm{mg} / \mathrm{kg}$ bb. Pada penelitian ini fenobarbital diberikan 30 menit setelah pemberian sediaan uji agar sediaan uji dapat diabsorpsi dengan baik. Pengaruh pemberian sediaan uji dapat dilihat berdasarkan onset (interval waktu setelah pemberian fenobarbital hingga hilangnya righting reflex) dan durasi (interval waktu mulai hilangnya righting reflex sampai muncul kembali righting reflex). Righting reflex dapat diartikan sebagai kemampuan pada hewan untuk kembali ke posisi semula sehingga kuku dan kakinya menempel ke tanah setelah sebelumnya diposisikan pada posisi atau dalam keadaan terlentang. Hilangnya righting reflex ditandai dengan ketidakmampuan mencit untuk kembali ke posisi normal (berdiri di atas keempat kakinya) dari keadaan terlentang apabila disentuh. Sedangkan munculnya righting reflex yang menyatakan berakhirnya waktu tidur ditandai dengan adanya kemampuan mencit untuk kembali ke posisi normal (berdiri dengan keempat kakinya).

Berdasarkan data diatas dapat disimpulkan bahwa EEBC dosis 400 $\mathrm{mg} / \mathrm{kgbb}$ menyebabkan onset tidur paling singkat yaitu 8,4 menit, kemudian EEBC dosis 200mg/kgbb yaitu 11,6 menit ; EEBC dosis $100 \mathrm{mg} / \mathrm{kgbb}$ yaitu 17,8 menit dan kontrol positif yaitu 18 menit. Sedangkan ekstrak yang menyebabkan durasi tidur paling lama yaitu EEBC dosis $400 \mathrm{mg} / \mathrm{kgbb}$ dengan waktu 217,8 menit, diikuti EEBC dosis 200 
$\mathrm{mg} / \mathrm{kgbb}$ dengan 182,6 menit dan EEBC $100 \mathrm{mg} / \mathrm{kgbb}$ yaitu 162,4 menit serta kontrol positif yaitu 155,2 menit dan kontrol normal tidak tidur sama sekali.

Hasil pengujian dilihat dari data dan diagram diatas serta diolah dengan statistik menunjukkan bahwa hanya sediaan uji ekstrak etanol bunga cengkeh pada dosis $400 \mathrm{mg} / \mathrm{kg}$ bb ratarata durasi selama 217,8 menit dapat memperpanjang durasi tidur mencit yang diinduksi dengan fenobarbital secara signifikan dibandingkan terhadap kontrol positif rata-rata durasi selama 155,2 menit pada $\mathrm{p}<0,05$; Sedangkan ekstrak etanol bunga cengkeh pada dosis $200 \mathrm{mg} / \mathrm{kg}$ bb ratarata durasi selama 182,5 menit dan dosis $100 \mathrm{mg} / \mathrm{kg}$ bb rata-rata durasi selama 162,4 menit tidak dapat memperpanjang durasi tidur mencit yang diinduksi dengan fenobarbital secara signifikan dibandingkan terhadap kontrol positif rata-rata durasi selama 155,2 menit pada $\mathrm{p}>0,05$. Dan ekstrak etanol bunga cengkeh pada dosis $400 \mathrm{mg} / \mathrm{kg}$ bb rata-rata onset selama 8,4 menit dan dosis $200 \mathrm{mg} / \mathrm{kg}$ bb rata-rata onset 11,6 menit dapat mempersingkat onset tidur mencit yang diinduksi dengan fenobarbital secara signifikan dibandingkan terhadap kontrol positif rata-rata onset selama 18 menit pada $\mathrm{p}<0,05$. Sedangkan ekstrak etanol bunga cengkeh pada dosis $100 \mathrm{mg} / \mathrm{kg}$ bb rata-rata onset selama 17,8 menit tidak dapat mempersingkat onset tidur mencit yang diinduksi dengan fenobarbital secara signifikan dibandingkan terhadap kontrol positif rata-rata onset selama 18 menit pada $\mathrm{p}>0,05$. Hasil ini menunjukan bahwa ekstrak etanol bunga cengkeh pada dosis $400 \mathrm{mg} / \mathrm{kg}$ bb dapat mempercepat onset tidur mencit dan memperpanjang durasi tidur mencit yang diinduksi fenobarbital.

\section{KESIMPULAN DAN SARAN}

\section{Kesimpulan}

Dari penelitian ini diperoleh hasil bahwa ekstrak etanol bunga cengkeh pada dosis $200 \mathrm{mg} / \mathrm{kgbb}$ dan dosis 400 $\mathrm{mg} / \mathrm{kgbb}$ dapat mempersingkat onset tidur pada mencit yang diinduksi dengan fenobarbital, berbeda bermakna terhadap kontrol positif ( $\mathrm{p}<0,05)$. Ekstrak etanol bunga cengkeh dosis $400 \mathrm{mg} / \mathrm{kg}$ bb juga dapat memperpanjang durasi tidur pada mencit yang diinduksi fenobarbital berbeda bermakna terhadap kontrol positif $(p<0,05)$.

\section{Saran}

Perlu dilakukan penelitian lebih lanjut mengenai uji toksisitas bunga cengkeh demi keamanan penggunaannya

\section{DAFTAR PUSTAKA}

Ulung, G., 2014, "Sehat Alami dengan Herbal", PT. Gramedia Pustaka Utama, Jakarta, Hlm. 132-133.

Pewe, E., 2006,“Apotek Hidup untuk Kesehatan Manusia", CV. Citra Cipta Purwosari, Jakarta, Hlm. 22, 28-29.

Pinto, E., Vale-Silva ,L., Cavaleiro, C., and L. Salgueiro., 2009, "Antifungal activity of the clove essential oil from Syzygium aromaticum on Candida, Aspergillus and Dermatophyte Species", Journal of Medical Microbiology, 58, 1454-1462.

Pandey, A., P. Singh., 2011 "Antibacterial activity of Syzygium aromaticum (clove) with metal ion effect against food borne pathogens",Asian 
Journal of Plant Science and Research, 1 (2):69-80.

Priyono, P. D. A., 2010, "Uji Afrodisiaka Infusa Kuncup Bunga Cengkeh (Syzygium aromaticum (L.) Meer\&Perry) terhadap Libido Tikus Jantan", Tugas Akhir Sarjana Farmasi, Fakultas Farmasi, Universitas Muhammadiyah Surakarta, Surakarta.

Adli, D. E. H., Kahloula, K., Silmani, M., Lahouel, Z., A. Belmahi., 2014, "The Efficacy of Syzygium aromaticum Essential Oil in Cognitive Disorders against Manganese Chronic Exposure in Rats during Development", Not Sci Biol, 6(2):131-137.

Dasti-R, M, H., A. Morshedi., 2009, "The effects of Syzygium aromaticum (clove) on Learning and Memory in Mice", Asian Journal of Traditional Medicinis, 4 (4).

Boudou, F., Berroukche, A., Bendahmane-Salmi, M., Kandouci, B, A., Adli, D. E. H., N. Tou., 3013, "Ameliorative Effects of Syzygium aromaticum Essential Oil on Fertility in Male Rats Exposed to Manganese", Advances in Sexual Medicine, 3, 85-91.

Puradisastra, S., Rosnaeni, dan I. Budiman., 2010, "Efek Hipnotik Biji Seledri (Apium Grafeolens L.) pada Mencit Jantan Galur Ddy dan
Pengaruhnya Terhadap waktu Reaksi Sederhana (WRS) pada Manusia", Jurnal, Fakultas Kedokteran, Universitas Kristen Maranatha, Bandung. HIm. 60.

Rahadian, D. D., 2009, "Pengaruh Ekstrak Biji Pala (MyristicafragnansHoutt) Dosis 7,5mg/25mgBB Terhadap Waktu Indeks Tidur dan Lama Waktu Tidur Mencit Balb/C yang Diinduksi Thiopental", Laporan Akhir Karya Tulis Ilmiah, Fakultas KedokteranUniversitas Diponegoro, Semarang. Hlm. 12.

Erasmo,

A.P.,2014,"Insomnia",http://ww w.medicinet.com/artikel/1187,D iakses21 september 2015.

Suyono, S., 2001, "Buku Ajar Ilmu Penyakit Dalam", Edisi III, Jilid 2, FKUI, Jakarta, Hlm. 778.

Nuzband, K. N., 2014, "Uji Aktivitas Antidepresan Ekstrak Bunga Cengkeh (Syzygium aromaticum) Pada Mencit Putih (Mus Musculus) Jantan Dengan Metode Forced Swim Test", Karya Tulis Ilmiah, Akademi Farmasi Samarinda, Samarinda, Hlm. 2, 7-8. 